ENTREPRENEURSHIP AND SUSTAINABILITY ISSUES

ISSN 2345-0282 (online) http://jssidoi.org/jesi/

2019 Volume 7 Number 2 (December)

http://doi.org/10.9770/jesi.2019.7.2(61)
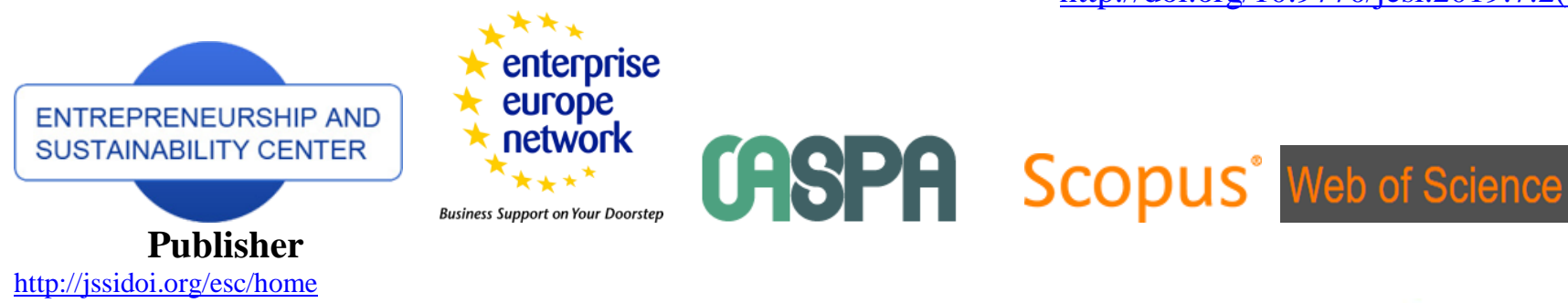

http://jssidoi.org/esc/home

1) Clarivate

Analytics

\title{
THE IMPACT OF THE PUBLICATION OF NON-FINANCIAL STATEMENTS ON THE FINANCIAL PERFORMANCE OF COMPANIES WITH THE IDENTIFICATION OF INTERSECTORAL FEATURES
}

\author{
Alex Borodin ${ }^{1}$, Nataliya Shash ${ }^{2}$, Galina Panaedova ${ }^{3}$, Svetlana Frumina ${ }^{4}$, Aidyn Kairbekuly ${ }^{5}$, \\ Irina Mityushina ${ }^{5}$ \\ 1,2 Plekhanov Russian University of Economics, 36, Stremyanny lane, Moscow, Russian Federation \\ ${ }^{3}$ North-Caucasus Federal University, 1, Pushkin str., Stavropol, Russian Federation \\ ${ }^{4}$ Financial University under the Government of the Russian Federation, 49, Leningradskij prospekt, Moscow, Russian \\ Federation \\ ${ }^{5}$ Nazarbaev Intellectual School in Semey city, 36-20, Glinki str., Semey, Republic of Kazakhstan \\ ${ }^{6}$ Belgorod National Research University, 85, Pobedy Street, Belgorod, 308015, Russian Federation
}

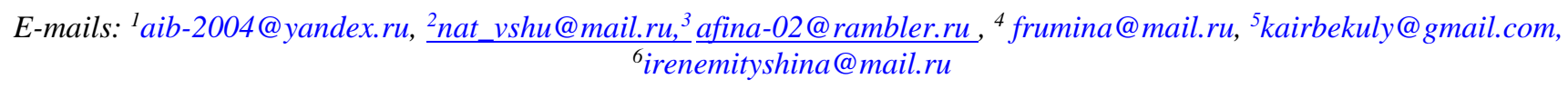

Received 18 August 2019; accepted 22 November 2019; published 15 December 2019

\begin{abstract}
Investor expectations, rather than fundamentals, are increasingly influencing the value of a company. At a time when nonfinancial assets are becoming an important component of determining the value of the company, the disclosure of non-financial statements as a source of more extensive and meaningful information than financial statements, is becoming an increasingly popular topic of discussion of the scientific and business communities. Non-financial reporting includes "various types of external reporting provided by organizations to their stakeholders and covering those aspects of the organizations that go beyond the historical framework of financial performance". The information contained in non-financial reports can help investors form an opinion about the intellectual, financial, natural, human and social capital of the company and make a decision about investing. In the developed world, the publication of nonfinancial statements has become a common norm, while in Russia only a small proportion of companies still issue this type of reporting. The study of publishing non-financial reports dedicated to both theoretical and empirical literature, most empirical studies showed a positive effect of issue of non-financial reporting on the financial stability of companies. However, these studies do not focus on the impact of the publication of non-financial statements on the financial performance of companies in Russia. The purpose of this article is to study the impact of the publication of non-financial statements on the financial performance of Russian companies with the identification of intersectoral features. As a result of this study, it will be possible to understand how the disclosure of non-financial information affects the financial performance of Russian companies. From a practical point of view, this can help managers of companies in various industries to realize the importance or, conversely, the absence of the need to publish non-financial statements as a factor that can increase the credibility of the company in the eyes of investors and positively affect the financial results.
\end{abstract}

Keywords: non-financial reporting; corporate sustainability; corporate social responsibility; non-financial information; cost of the company; financial statements; profitability of assets; sustainable development 


\section{ENTREPRENEURSHIP AND SUSTAINABILITY ISSUES}

ISSN 2345-0282 (online) http://jssidoi.org/jesi/

2019 Volume 7 Number 2 (December)

http://doi.org/10.9770/jesi.2019.7.2(61)

Reference to this paper should be made as follows: Borodin, A., Shash, N., Panaedova, G., Frumina, S., Kairbekuly, A., Mityushina, I. 2019. The impact of the publication of non-financial statements on the financial performance of companies with the identification of intersectoral features. Entrepreneurship and Sustainability Issues, 7(2), 1666-1685. http://doi.org/10.9770/jesi.2019.7.2(61)

JEL Classifications: G30, G31

\section{Introduction}

Non-financial reporting can be described as the practice of measuring and disclosing information about a company's sustainable development to a wide range of stakeholders, mainly shareholders. Sustainable development is understood to be one in which the needs of present generations are met without compromising the ability of future generations to meet their own needs. The concept of sustainable development consists of three main aspects: economic, social and environmental (Crowther, 2009). The social dimension implies a company's understanding of the impact of its activities on social well-being (both private and global) and a willingness to take moral responsibility for decisions and their consequences in the area of social well-being and inequality. The economic dimension of sustainable development implies the need for efficient and equitable distribution and use of productive resources to maintain a balance between short-term and long-term economic growth. The environmental aspect points to the need to reduce the negative impact of the company's activities on the environment, especially on non-renewable natural resources, as well as the adoption of measures for the transition to environmentally friendly production. Companies include in their reports information on risks and prospects of development on the three most important aspects of sustainable development; on the role of the company in the economy of the region, the country and the world; on social, sports, educational, creative, environmental, charitable and sponsorship events; about conditions and labor protection and health, creation of opportunities for development of employees, etc. Companies' activities towards sustainable development and disclosure of nonfinancial information have both benefits and costs. Depending on which effect is stronger, disclosure of nonfinancial information can have both a positive and negative impact on financial performance. Moreover, whether a positive impact will be revealed depends on the characteristics of the country as a whole, and on the specific industry or market in which the company operates, and on the characteristics of the firm. In practice, there are studies that have identified both the presence and absence of a positive relationship.

\section{Litreture review}

\subsection{Studies that revealed the positive effect of the publication of non-financial information on financial performance}

Over a long period of time, professionals from various fields analyze whether socially responsible behavior of companies can have an impact on their financial condition, both short-term and long-term. To date, a significant number of studies have been conducted, using various methodologies and samples, which revealed the presence of a positive impact of the publication of non-financial statements on financial performance.

Thus, one of the first studies was the work "Differences in Social-Cost Disclosures: a Market Test of Investor Reactions" (Freedman, \& Stagliano 1991). The study followed a decision by the U.S. Supreme Court to require cotton textile mills to disclose compliance with environmental standards. This was a unique case, on the example of which it was possible to observe the reaction of investors. The reaction of investors to the exogenous factor that affected a certain group of companies was studied. In this paper, the estimated effects paradigm is applied in the framework of the standard market model for assessing the reaction of investors to the news that textile factories will be required to meet a new expensive requirement in the field of occupational safety and health. In order to 


\section{ENTREPRENEURSHIP AND SUSTAINABILITY ISSUES}

ISSN 2345-0282 (online) http://jssidoi.org/jesi/

2019 Volume 7 Number 2 (December)

http://doi.org/10.9770/jesi.2019.7.2(61)

determine the potential financial impact of the new standard, the sample of companies was divided into subgroups based on the volume and type of information published. In most cases, investors reacted positively to the publication of reports, despite the fact that compliance with the standards meant higher costs for companies. This may have been due to the fact that firms ' reporting became more transparent, resulting in reduced uncertainty and increased attractiveness. This study was followed by many studies that showed a positive relationship between non-financial reporting and financial performance in different samples Pava, \& Krausz (1996).

The study "the corporate social-financial performance relationship Preston, \& O'bannon (1997) was one of the largest works of the last century, and covered a sample of the largest us companies in the period 1982-1992. The study did not reveal a negative relationship between social and financial success, but confirmed the presence of a positive relationship using different regression models.

However, soon there were studies that questioned the causal relationship between the publication of non-financial statements and financial indicators. Thus, the main argument is that the management of companies begin to pay attention to the issues of social responsibility, when there is a sustainable financial development, that is, the issue of endogeneity. Moreover, not all studies included control variables in the models. Schreck (2011) thus, McWilliams, \& Siegel (2010) proved that development and research costs are an important component of models, the omission of which can lead to altered results. In Moore (2001), it was shown that company size also needs to be included in models.

In his study "Reviewing the Business Case for Corporate Social Responsibility: New Evidence and Analysis" Schreck (2011), on the basis of the studied works, he tried to develop a model in which the problem of endogeneity would be absent. The financial success of the company was considered in two categories: balance sheet indicators and market indicators, for which regressions were separately constructed. The author chose ROE as a balance indicator, Tobin's q as a market indicator. Based on 2006 data on three hundred us companies, the OLS regression model was constructed, where the following control variables were included among the explanatory variables: level of social responsibility, size of the company, level of risk and level of leverage. His model showed a positive relationship, but adherence to the concept of sustainable development does not always lead to improved financial performance.

However, the results of such studies can vary greatly depending on the market. Similar studies have been conducted in other samples, including emerging markets. Thus, the study "Environmental disclosure quality: Evidence on environmental performance, corporate governance and value relevance" Iatridis (2013) focuses on the Malaysian market, which belongs to the category of advanced emerging markets. The author examines the relationship between the level of disclosure of information about the company's policy in the field of environmental care and financial performance. The paper describes the relationship between the quality of disclosure and corporate governance, and raises the question of the extent to which the quality of disclosure of environmental information affects the perception of investors. The results of the study showed that disclosure of environmental information is usually correlated with the size of the company, the need for capital, profitability and capital expenditure. High quality disclosure is associated with effective corporate governance, making it easier for companies to access the capital market. Typically, companies with high quality non-financial reporting are serviced by audit companies from the big four, traded on foreign exchanges and show a higher level of managerial and institutional ownership. Thus, the author comes to the conclusion that the publication of nonfinancial statements really leads to an improvement in the perception of investors and increase the value of the company. He also notes that in Malaysia, the publication is common in such industries as chemical, food, forestry, metallurgy.

The relationship in Finland was confirmed in Communication via responsibility reporting and its effect on firm value in Finland (Schadewitz, \& Niskala 2010). The authors investigated how the publication of non-financial 


\section{ENTREPRENEURSHIP AND SUSTAINABILITY ISSUES}

ISSN 2345-0282 (online) http://jssidoi.org/jesi/

2019 Volume 7 Number 2 (December)

http://doi.org/10.9770/jesi.2019.7.2(61)

statements affects the value of the company, the object of the study were Finnish companies in the period 20022005. The analysis was conducted using a traditional valuation model that included non-financial reporting as a variable. Non-financial reporting was measured as the presence or absence of a non-financial reporting report in accordance with GRI standards. The authors were able to confirm that the communication of the company with agents through the channels of publication of non-financial reporting GRI is an important factor explaining the value of the company. The researchers explain the result by the fact that in this way the firm gets access to the means of communication, which leads to a decrease in the asymmetry of information between managers and investors.

\subsection{Empirical studies that have not revealed a positive effect of the publication of non-financial information on financial performance}

The study "the relationship between corporate social performance and corporate financial performance in the banking sector" Soana (2011) analyzes the same relationship, but on a specific sector - banking, but it does not reveal a positive effect. The study was conducted on a sample of 68 Italian and international banks in 2005. The impact on financial indicators such as ROA (return on assets ratio), ROE (return on equity-ratio), P/E (price to earning ratio) and MTBV (market to book value) was taken into account. According to the results, there is no statistically significant dependence of indicators of sustainability of banking sector companies and their financial performance. However, it is worth noting that the control variables were not included in the model of this work.

In another study, "The value relevance of intellectual capital disclosures" Vafaei, et al. (2011), on the contrary, was shown that in non-traditional industries (which include the banking sector) presents positive impact of disclosure of non-financial information on financial results. However, in traditional industries such dependence was not detected, moreover, in the sample there were companies from four countries, and the dependence was confirmed in only two of them. Thus, companies from the UK, Austria, Singapore and Hong Kong were divided into traditional and non-traditional industries. The authors studied the impact of non-financial disclosure on the company's net income and assets. In the UK, a positive effect was found in non-traditional industries on both net profit and asset value, while in traditional industries, no such dependence was found. In Austria, the positive impact was also seen only in non-traditional industries, but the positive impact was only on the value of assets, not on net profit. This may be because disclosure reduces uncertainty and also allows investors to reassess the company's intangible assets and improve the long-term Outlook for the company's future earnings, but in the short term this has no impact on profits. In Singapore and Hong Kong, it was not possible to find a significant positive impact. In the sample for traditional industries (without country differentiation), no positive effect was found, and in non-traditional industries, a positive relationship was found. Thus, the presence or absence of dependence is an individual characteristic for different countries and industries.

However, it is worth noting that there were sample limitations in this study. For example, in Hong Kong, companies provided less complete reporting, but there was no differentiation in the quality of reporting provided. Companies from non-traditional industries were on average younger and smaller, but variables (such as company size were not included in the model). It can be assumed that the identified effect for non-traditional industries is not due to the company's commitment to a particular industry, but to the fact that it is younger, which means that investors have less information about it, and the level of uncertainty is higher. In this regard, the disclosure of non-financial information has a significant effect on the perception of the company.

\section{Methodology}

There are many non-financial reporting standards, and the question for researchers is how to account for disclosure non-financial reporting. Companies are represented on the market, which publish environmental 


\section{ENTREPRENEURSHIP AND SUSTAINABILITY ISSUES}

ISSN 2345-0282 (online) http://jssidoi.org/jesi/

2019 Volume 7 Number 2 (December)

http://doi.org/10.9770/jesi.2019.7.2(61)

reports, social reports, reports in sustainable development areas, integrated and industry reports, and they are compiled in accordance with different standards. In this regard, an important question is what types of reporting to use for the study.No less important is the question of the set of financial indicators which to choose as explained. After choosing the indicators to be explained, it is necessary to make a decision on which indicators to take into account as benchmarks.

\section{Financial performance explained}

When selecting the indicators to be explained, it is important, on the one hand, to select enough variables to have a complete picture, with on the other hand, not to include too many explicable variables, as it can lead to deterioration of the quality of the study, because either additional models simply will not give new information, or the results may be contradictory. And in a situation when you were not initially selected to explain the main variables that can cause problems with interpretation. $\mathrm{C}$ the impact of disclosure is analyzed non-financial information on financial indicators:

1) The ratio of market value to book value (Q-Tobin);

2) Return on assets ratio (ROA).

The basic theory of corporate Finance, the main task management is to maximize the value of the company, that is, actions in interest of investors. In this regard, it was decided to take into account the impact disclosure of nonfinancial information on market value, however an analysis of the value gain in itself would be incorrect for several reasons. It can be a consequence of changes in the balance sheet the value of assets, such as additional investments or payments dividends'. To avoid inaccuracies, a decision was made analyze the impact on the growth of the ratio of market value to balance sheet (Q-Tobin). Also, this indicator allows you to get rid of errors related to ignoring differences in the capabilities of companies, reasonable different amount of available assets and size. Q-Tobin allows you to analyze the market value taking into account this difference, then there are adjusted for the size of the assets. It was also interesting to see if a gain in the cost of this indicator, it is due to fundamental reasons or such as changing investor perceptions and expectations about future success of the company. For this purpose the decision was made analyze the increase in return on assets as a result of the publication non-financial reporting. Return on assets (ROA) is equal to net income to the value of assets, that is, reflects the change in the fundamental indicator (profitability of the company) adjusted for the company's ability to generate profit (per asset size). Thus, the financial indicators to be explained were one is selected to show the change in investor expectations for firms (Q-Tobin), and one fundamental (ROA). Additional explained variables were not included because they do not research significance was discovered and the interpretation would be difficult.

\section{Accounting for non-financial statements}

In this article as examples of disclosure of non-financial information will be considered reports in the field of sustainable development. Most recent studies have examined the impact of this type of reporting on financial performance, due to the fact that it is a fairly complete source of information for various stakeholders. There are several non-financial reporting disclosure standards: the Global Reporting Initiative (GRI), the International Integrated Reporting Council (IIRC), and the Sustainability Accounting Standards Board (SASB). Thus, according to some scientists (Hohnen, 2012), reports on GRI standards most fully disclose information about the company's activities, as well as are the most popular and requested by investors (greenbiz Intelligence Panel Study, 2013). In his work (Daizy \& Das, 2014) points out that GRI standards require disclosure based on more than 90 indicators of social responsibility, while other standards-much less. 


\section{ENTREPRENEURSHIP AND SUSTAINABILITY ISSUES}

ISSN 2345-0282 (online) http://jssidoi.org/jesi/

2019 Volume 7 Number 2 (December)

http://doi.org/10.9770/jesi.2019.7.2(61)

(Hohnen, 2012) showed that GRI standards are the most used among non-financial reporting companies. According to the study, 95\% of American companies, recognized as the most successful in the context of sustainable development in 2010, prepared reports according to GRI standards. Moreover, the GRI standards have been developed including through surveys of different groups of shareholders and reflect information of interest to different investors.

Thus, it is advisable to include in the study sample data on companies that publish reports on GRI standards. However, among the companies there are those that publish high-quality reports on non-financial information, but they are compiled in accordance with other standards. After reviewing their reports, it was decided to include these companies in the sample for several reasons. First, although many reports were not formally prepared in accordance with the GRI standards and are not included in the GRI database, they reflect most of the nonfinancial information required by this standard. So, not including their selection, it is possible to lose a large number of companies that are relevant for this study. Secondly, there are few companies in Russia compared to developed countries that practice disclosure of non-financial information, moreover, not all of them are available all the necessary information for the study, and the loss of some companies can lead to a significant deterioration in the results of the study. In this regard, this article takes into account all companies that publish reports on sustainable development, data on the publication of reports obtained from GRI sitesIn this article as examples of disclosure of non-financial information will be considered reports in the field of sustainable development. Most recent studies have examined the impact of this type of reporting on financial performance, due to the fact that it is a fairly complete source of information for various stakeholders. There are several non-financial reporting disclosure standards: the Global Reporting Initiative (GRI), the International Integrated Reporting Council (IIRC), and the Sustainability Accounting Standards Board (SASB). Thus, according to some scientists (Hohnen, 2012), reports on GRI standards most fully disclose information about the company's activities, as well as are the most popular and requested by investors ( greenbiz Intelligence Panel Study, 2013).

In his work (Daizy \& Das, 2014) points out that GRI standards require disclosure based on more than 90 indicators of social responsibility, while other standards-much less. Also, according to (Willis, 2003), GRI provides a reporting structure that can be used by companies regardless of size and industry. In accordance with the recommendations, Companies can independently prepare non-financial statements without the involvement of external organizations and improve their reputation as a socially responsible enterprise.

(Hohnen, 2012) showed that GRI standards are the most used among non-financial reporting companies. According to the study, 95\% of American companies, recognized as the most successful in the context of sustainable development in 2010, prepared reports according to GRI standards. Moreover, the GRI standards have been developed including through surveys of different groups of shareholders and reflect information of interest to different investors.

Thus, it is advisable to include in the study sample data on companies that publish reports on GRI standards. However, among the companies there are those that publish high-quality reports on non-financial information, but they are compiled in accordance with other standards. After reviewing their reports, it was decided to include these companies in the sample for several reasons. First, although many reports were not formally prepared in accordance with the GRI standards and are not included in the GRI database, they reflect most of the nonfinancial information required by this standard. So, not including their selection, it is possible to lose a large number of companies that are relevant for this study. Secondly, there are few companies in Russia compared to developed countries that practice disclosure of non-financial information, moreover, not all of them are available all the necessary information for the study, and the loss of some companies can lead to a significant deterioration in the results of the study. In this regard, this article takes into account all companies that publish reports on sustainable development, data on the publication of reports obtained from GRI sites. 


\section{ENTREPRENEURSHIP AND SUSTAINABILITY ISSUES}

ISSN 2345-0282 (online) http://jssidoi.org/jesi/

2019 Volume 7 Number 2 (December)

http://doi.org/10.9770/jesi.2019.7.2(61)

\section{Statement of hypotheses}

The article will analyze how the publication of non-financial statements affects the increase in the ratio of market value to the balance sheet and the increase in the return on assets (ROA). It is assumed that there is a positive effect of the publication of non-financial statements on these indicators. The article will analyze how the publication of non-financial statements affects the increase in the ratio of market value to the balance sheet and the increase in the return on assets (ROA). It is assumed that there is a positive effect of the publication of nonfinancial statements on these indicators.

Why this article assumes a positive effect disclosure of non-financial information on Q-Tobin? Q-Tobin is one of the most popular explicable financial indicators in such studies. This figure takes into account changing expectations of investors regarding the company's market value to book value, that is, takes into account changing expectations with respect to various parameters influencing the evaluation of future cash flows.

Why is the positive effect of disclosure assumed non-financial information on ROA? As mentioned above, many researchers say predict that investing in programs sustainable development in the long term leads to the growth of the company and an increase in asset-generated profits. Accordingly, and ROA (the ratio of net profit to book value of assets) should will increase. It is also an indicator of the growth of the financial the success of the company to isolate the fundamental parameter.

It seems more logical that the effect on the publication of a non-financial report on Q-Tobin will be more shortterm than on ROA. Q-Tobin can quickly change as a result of investors ' reassessment of future cash flows and, accordingly, the value of the company. After the revaluation has already been carried out, the reports published in the past should not affect Q-Tobin. However, if the flow of these funds begins to come to the company and increase profits only in the future, it will be possible to say that the ROA indicator changes as a result of the disclosure of non-financial information with a time lag.

It is also worth noting that for companies from some industries, the effect can be much stronger than for companies from other industries. Investors, who make decisions, pay more attention to different aspects in different industries, and we can assume that for some industries the effect will be particularly strong, while for companies from other industries there will be no positive effect of the publication of non-financial statements on financial performance. In this regard, it was decided to look at the relationship between the disclosure of nonfinancial information and financial indicators not only in the whole sample, but also to study the effect on different industries.

The article will be tested the following hypotheses:

(H1) the Publication of non-financial statements results in an increase in the ratio of the market value of capital to the balance sheet starting in the year following publication.

$(\mathrm{H} 2)$ the Publication of non-financial statements results in an increase in return on assets starting in the year following publication.

(H3) the effect of the publication of non-financial statements on the ratio of the market value of capital to the balance sheet is not evident in all industries.

(H4) the effect of the publication of non-financial statements on return on assets is not apparent in all industries.

The methodology for selecting explanatory variables was as follows: first, on the basis of logic and literature, a list of possible control variables was built (ROE, book value of assets, EPS, leverage, R\&D expenses to revenue ratio, revenue volume), subsequently, to test the tests for significance and multicollenarity, the variables were left to explain Q-Ttobin: book value of assets, leverage, and to explain ROA: book value of assets, EPS, leverage. 


\section{ENTREPRENEURSHIP AND SUSTAINABILITY ISSUES}

ISSN 2345-0282 (online) http://jssidoi.org/jesi/

2019 Volume 7 Number 2 (December)

http://doi.org/10.9770/jesi.2019.7.2(61)

The proposed set of explanatory variables included such indicators as company revenue (Sales) (Lopez, Garcia, Rodriguez, 2007) and EPS, as changes in stock returns can stimulate or discourage investors to make a decision in favor of investing in the company, and therefore affect the financial success. Moreover, ROE was included in the list of supposed explanatory variables, since, presumably, like EPS, it can influence the mood of investors, and thus the demand for the company's shares, and therefore the financial performance. Also, the growth of financial indicators is affected by the value of this indicator in the past year, so to explain the growth of Q-Tobin in the model was included Q-Tobin of the previous year, and to explain the growth of ROA-ROA of the next year. The model was included Q-Tobin of the previous year, and to explain increase in ROA-ROA of the previous year.

\section{The sampling design}

The sample included companies for the period 2008-2018. The following data were uploaded for each company.

The first part of the sample companies (companies that published non-financial reporting), was compiled according to the following criteria:

1. Availability of publication of non-financial statements in accordance with lists of companies from the GRI website at least in one year.

2. Commercial public company.

3. Availability of financial information required for research (in Bloomberg or in reporting on the company's website).

The second part of the sample companies (companies that have not published non-financial reporting), was compiled according to the following criteria:

1. The company has never published financial statements (there is no information about the publication on the GRI website).

2. Commercial public company.

3. Belonging to the industry in which companies are present, publishing non-financial statements.

4. Availability of necessary financial information.

After cleaning the data the sample consisted of 106 companies 8 industries economies. Among these companies, 62 have published non-financial statements at least once and 44 have never published them. Companies that did not publish reports were selected in this way so that each sector has the same structure of companies, publishing and non-publishing reports. However, the full the symmetry of the companies could not be preserved for several reasons. Thus, almost all companies with financial performance data related to "basic materials " publish nonfinancial statements, so we had to choose between the number of observations and maintaining the similarity of the structures of the two subsamples: publishing and non-publishing companies. The choice was made to retain the sample size. This is not a big limitation, and the vast majority of studies analyzing the effect of non-financial disclosure have been conducted on asymmetric samples.

The following figures for 2008-2018 were uploaded for all companies (Table 1): 


\section{ENTREPRENEURSHIP AND SUSTAINABILITY ISSUES}

ISSN 2345-0282 (online) http://jssidoi.org/jesi/ 2019 Volume 7 Number 2 (December) http://doi.org/10.9770/jesi.2019.7.2(61)

Table 1. Financial performance

\begin{tabular}{|c|c|c|c|}
\hline Indicator & Formula & Description & $\begin{array}{l}\text { Expected } \\
\text { influence } \\
\text { infection of oxplained } \\
\text { variables }\end{array}$ \\
\hline RETURN_ON_ASSET & $\begin{array}{l}\text { Net income / Assets of the } \\
\text { company }\end{array}$ & $\begin{array}{l}\text { A measure of how profitable a company is } \\
\text { in relation to its total assets, as a } \\
\text { percentage. ROA gives an idea of how } \\
\text { effectively management manages the } \\
\text { assets of the company for profit. }\end{array}$ & Explained \\
\hline RETURN_COM_EQY & Net income / equity & $\begin{array}{l}\text { A measure of the company's return on } \\
\text { funds invested by shareholders, as a } \\
\text { percentage.A measure of the company's } \\
\text { return on funds invested by shareholders, } \\
\text { as a percentage. }\end{array}$ & Positive \\
\hline TOBIN_Q_RATIO & $\begin{array}{l}\text { market value of the } \\
\text { company / book value of the } \\
\text { company }\end{array}$ & $\begin{array}{l}\text { The ratio of the market value of the } \\
\text { company to the book value. The Tobin } \\
\text { ratio is based on the hypothesis that in the } \\
\text { long run the market value of the company } \\
\text { should be approximately equal. }\end{array}$ & Explained \\
\hline EPS & $\begin{array}{l}\text { Net income / number of } \\
\text { common shares }\end{array}$ & $\begin{array}{l}\text { Represents the proportion of the company's } \\
\text { profit distribution among shareholders. }\end{array}$ & Positive \\
\hline RD & $\begin{array}{l}\text { The costs of research and } \\
\text { development / revenue }\end{array}$ & $\begin{array}{l}\text { Reflects the ratio of total research } \\
\text { expenditure to developments that include } \\
\text { R\&D in the income statement and loss } \\
\text { account and capitalised R\&D to revenue } \\
\text { during the period's. }\end{array}$ & Positive \\
\hline TOTAL SALES & Total revenue & $\begin{array}{l}\text { Characterizes the total amount of income } \\
\text { received by the firm during the year. }\end{array}$ & Positive \\
\hline BS_TOT_ASSET & Book value of assets & $\begin{array}{l}\text { The total amount of all current and long- } \\
\text { term assets recorded in the balance sheet. } \\
\text { Displays the size of the company, in our } \\
\text { model will play the role of a control } \\
\text { variable. }\end{array}$ & Positive \\
\hline $\begin{array}{l}\text { TOT_DEBT_TO_ } \\
\text { EQUITY }\end{array}$ & the company's debt / equity & $\begin{array}{l}\text { The coefficient determines the total } \\
\text { amount of debt on } \\
\text { relative to assets; allows you to compare } \\
\text { leverage between different companies. }\end{array}$ & Negative \\
\hline Published & $\begin{array}{l}\text { Published }=1 \text { if there are } \\
\text { non-financial statements; } \\
\text { Published }=0 \text { if there are no } \\
\text { non-financial statements. }\end{array}$ & $\begin{array}{l}\text { Dummy is a variable that indicates whether } \\
\text { a company has published information } \\
\text { about non-financial indicators or not. }\end{array}$ & Positive \\
\hline
\end{tabular}

Source: GRI (2019). Sustainability Reporting. https://www.globalreporting.org/information/sustainability-reporting/Pages/default.aspx

After collecting panel data, it was decided to exclude variable "the ratio of research expenditures to revenue»" There were a lot of omissions in the R\&D spending data, which could not be recovered even after searching for information in reports on company websites. When trying to replace omissions with "averages", the R\&D variable was negligible. When companies that do not have R\&D data are excluded from the sample, the sample is greatly reduced. Therefore, it was decided not to include this variable in the analysis. In total there were 261 observations with publication and 312 observations without publication of non-financial statements.

\section{Descriptive statistics}

Despite the fact that there were 162 companies mentioned in the lists of companies that published non-financial statements on the GRI website, only 62 companies met the criteria for entering the sample, for these companies there were 261 observations in just 10 years. The number of companies that did not publish reports is 44 , the number of observations is 312 . 
Despite the fact that there were 162 companies mentioned in the lists of companies that published non-financial statements on the GRI website, only 62 companies met the criteria for entering the sample, for these companies there were 261 observations in just 10 years. Quantity companies that have not published reports -44, the number of observations 312. Below is the distribution of observations by year (Table 2).

Table 2. The number of observations in the time section.

\begin{tabular}{|l|l|l|}
\hline Year & Number of published companies & Number of unpublished companies \\
\hline 2018 & 37 & 41 \\
\hline 2017 & 32 & 35 \\
\hline 2016 & 29 & 34 \\
\hline 2015 & 30 & 36 \\
\hline 2014 & 28 & 29 \\
\hline 2013 & 27 & 27 \\
\hline 2012 & 25 & 25 \\
\hline 2011 & 22 & 29 \\
\hline 2010 & 13 & 24 \\
\hline 2009 & 11 & 18 \\
\hline 2008 & 7 & 14 \\
\hline
\end{tabular}

Thus, it was found that on average, companies that publish non-financial reporting, larger. This can be seen from Table 3, which shows the ratio of the average book value of companies, non-financial statements, to the average book value companies that do not publish non-financial statements. Almost everything this ratio was more than one. When interpreting the results it should be noted that the first group of companies, on average, had more financial opportunities.

It is also worth noting that on average, Q-Tobin is higher in companies, publishing non-financial statements. This can be seen from (Table 3), reflecting the Q -Tobin ratio of published companies to unpublished. As you can see, every year this ratio is greater than 1 , so in companies that publish non-financial statements have more than I'm Tobin. This allows us to make the assumption that the publication of non-financial statements leads to an increase in the ratio of market value to book value. However such assumptions can be too hasty, since the inverse relationship is likely: more large and successful companies take care to disclose non-financial information.

Table 3. The ratio of the average TA, Q- Tobins and ROA of published companies to unpublished

\begin{tabular}{|l|l|l|l|l|l|l|l|l|l|l|l|}
\hline Year & 2018 & 2017 & 2016 & 2015 & 2014 & 2013 & 2012 & 2011 & 2010 & 2009 & 2008 \\
\hline$T A$ & 2.434 & 1.902 & 1.841 & 1.786 & 0.980 & 1.154 & 2.288 & 4.015 & 3.154 & 6.018 & 5.318 \\
\hline$Q$ & 3.144 & 4.801 & 1.649 & 2.357 & 4.212 & 3.210 & 6.237 & 8.531 & 6.104 & 4.714 & 3.246 \\
\hline ROA & 1.014 & 0.849 & 1.084 & 0.724 & 0.991 & 0.674 & 1.463 & 2.100 & 1.151 & 0.986 & 0.768 \\
\hline
\end{tabular}

It can also be seen from Table 3 that there is no clear heterogeneity in a sample of the return on assets. The ratio of the average the ratio of profitability of published companies to unpublished in four years more than one, and six years less than one.

Next, we pay attention to the correlation of dependent variables (Table 4). 


\begin{tabular}{|c|c|c|c|c|c|c|c|c|}
\hline & roa & roe & tobins_q & eps & total_assets & total sales & debt_to_equity & published \\
\hline roa & 1.00 & 0.52 & 0.05 & 0.06 & 0.01 & 0.64 & -0.32 & 0.11 \\
\hline roe & 0.52 & 1.00 & 0.20 & 0.08 & 0.02 & 0.32 & -0.15 & 0.06 \\
\hline tobins_q & 0.05 & 0.20 & 1.00 & -0.01 & -0.06 & 0.44 & 0.30 & 0.05 \\
\hline eps & 0.06 & 0.08 & -0.01 & 1.00 & 0.00 & 0.10 & 0.00 & 0.04 \\
\hline total_assets & 0.01 & 0.02 & -0.06 & 0.00 & 1.00 & 0.32 & -0.03 & 0.11 \\
\hline total sales & 0.64 & 0.32 & 0.44 & 0.00 & 0.32 & 1.00 & 0.11 & 0.28 \\
\hline debt_to_equity & -0.32 & -0.15 & 0.30 & 0.00 & -0.03 & 0.11 & 1.00 & -0.07 \\
\hline published & 0.11 & 0.06 & 0.05 & 0.04 & 0.11 & 0.28 & -0.07 & 1.00 \\
\hline
\end{tabular}

Interestingly, the debt_to_equity parameter is negatively related to ROA and ROE, while positively associated with Q-Tobin. That is in our sample the following trend is observed: the higher the financial leverage, the lower Forty one return on equity and return on equity, while leverage is positively related to the company's market value ratio to the balance sheet. We assumed that leverage would be negatively related as with ROA, so with Q-Tobin, since big leverage means risk. However, as can be seen, the connection with Q-Tobin is positive, this can be explained by the fact that companies that borrow money save on taxes, which leads to increase the value of the company. However, with ROA, the relationship is negative. In addition, Q-Tobin was negatively related to EPS and asset value (TA), other variables correlate positively.

\section{Results' analysis}

To begin with, the $\mathrm{H} 1$ and $\mathrm{H} 2$ hypotheses were tested, which state that there is a positive relationship between the publication of non-financial statements and the Q-Tobin and ROA coefficients, respectively.

The first step was to build a regression in which all variables were included:

$$
\begin{aligned}
Q, \text { ROAdel } & =\beta_{1}+\beta_{2} \text { TA }+\beta_{3} Q+\beta_{4} D E+\beta_{5} \text { TS }+\beta_{6} \text { EPS }+\beta_{7} R O A+\beta_{8} \text { published }(t) \\
& +\beta_{9} \text { published }(t-1) \\
& +\beta_{10} \text { published }(t-2)+\cdots+\beta_{14} \text { published }(t-6)+U_{i}
\end{aligned}
$$

where Qdel- $\frac{Q_{t+1}-Q_{t}}{Q_{t}}$ (Q-the ratio of market value to book value in the corresponding year);

published ( $\mathrm{t}$ ) - dummy variable that displays the presence or absence of a non-financial report in period $\mathrm{t}$;

TA - the value of total assets, reflecting the size of the company;

$\mathrm{DE}$ - the ratio of debt to equity;

TS-total revenue;

EPS-earnings per share;

ROE-return on equity;

Q-the ratio of market value to book value in the period t. 
Lags greater than the sixth degree were not included, since it was decided that this only complicate the model. However, there were minor variables in the original model and multicollinearity was present, which was detected by the VIF test (Table 5):

Table 5. The results of VIF test for the inclusion of all variables (H1), (H2):

\begin{tabular}{|l|l|l|}
\hline Variable & VIF $(\mathrm{H} 1)$ & $\mathrm{VIF}(\mathrm{H} 2)$ \\
\hline TA(total asset) & 1.23 & 2.14 \\
\hline Q-tobins & 1.43 & 1.06 \\
\hline DE & 2.05 & 2.44 \\
\hline TS & 10.04 & 6.42 \\
\hline EPS & 9.36 & 3.12 \\
\hline ROE & 8.16 & 11.14 \\
\hline published(t) & 12.56 & 11.11 \\
\hline published(t-1) & 3.08 & 4.01 \\
\hline published(t-2) & 2.76 & 2.91 \\
\hline published(t-3) & 1.27 & 1.45 \\
\hline published(t-4) & 1.70 & 1.99 \\
\hline published(t-5) & 1.11 & 1.09 \\
\hline published(t-6) & 1.08 & 1.04 \\
\hline
\end{tabular}

H1: After the VIF test, it was decided to remove from the regression such explanatory variables like TS, EPS, ROE. This will not lead to a significant deterioration in predictive power, as the data the variables were not of high importance or were insignificant: p-value for TS, EPS, ROE was equal to $0.09 ; 0.34$ and 0.08 , respectively Since published $(\mathrm{t})$ has a high VIF, it cannot be included in the regression. It was decided to divide the hypothesis testing into two stages: first, to check the significance of the published (t) coefficient, and then to include lags in the model to analyze the presence of long-term influence.

H2: It was decided to remove the variables TS and ROE, their p-value were 0.11 and 0.26 , that is, they were not significant. By analogy with the hypothesis 1 test, two regressions were constructed: one involving the variable published $(\mathrm{t})$ and the variables with lags.

And so, models were built:

Model 1 (H1).

$$
Q \text { del }=\beta_{1}+\beta_{2} T A+\beta_{3} Q+\beta_{4} D E+\beta_{5} \text { published }(t)+U_{i}
$$

Model 2 (H1).

$$
\begin{gathered}
\text { Qdel = } \beta_{1}+\beta_{2} T A+\beta_{3} Q+\beta_{4} D E+\beta_{5} \text { published }(t-1)+\beta_{6} \text { published }(t-2) \\
+\beta_{7} \text { published }(t-3)++u \text { blished }(t-6)+U_{i}
\end{gathered}
$$


Model 3 (H2).

$$
\text { ROAdel }=\beta_{1}+\beta_{2} T A+\beta_{3} R O A+\beta_{4} E P S+\beta_{5} D E+\beta_{6} \text { published }+U_{i}
$$

Model 4 (H2).

$$
\begin{aligned}
\text { ROAdel }= & \beta_{1}+\beta_{2} \text { TA }+\beta_{3} R O A+\beta_{4} E P S+\beta_{5} D E+\beta_{6} \text { published }(t-1) \\
& +\beta_{7} \text { published }(t-2) \\
& +\beta_{8} \text { published }(t-3)+\cdots+\beta_{11} \text { published }(t-6)+U_{i}
\end{aligned}
$$

The following estimates were obtained for the first (H1) and third (H2) models (Table 6):

Table 6. Coefficients for model $1(\mathrm{H} 1)$ and $3(\mathrm{H} 2)$

\begin{tabular}{|l|l|l|c|c|}
\hline \multirow{2}{*}{} & \multicolumn{1}{|c|}{ Coefficient } & \multicolumn{2}{c|}{ P-value } \\
\cline { 2 - 5 } & \multicolumn{1}{|c|}{ Model 1 (H1) } & \multicolumn{1}{|c|}{ Model 3 (H2) } & Model 1 (H1) & 0.004 \\
\hline const & 0.11 & 0.06 & 0.14 & 0.07 \\
\hline$T A$ & $-0,57^{* *}$ & $0,415^{* *}$ & 0.03 & 0.08 \\
\hline ROA & $0.024^{*}$ & & & 0.13 \\
\hline DE & & $-0.031^{*}$ & 0.009 & 0.012 \\
\hline EPS & $-0,592^{* * *}$ & $-0,713^{* * *}$ & & 0.07 \\
\hline published & & $0,182^{*}$ & 0.089 & 0.23 \\
\hline R & $0,08^{2}$ & 0,066 & & \\
\hline
\end{tabular}

Model 1 (H1): An F-test was conducted on the insignificance of regression, which rejected the null hypothesis of insignificance. It has been hypothesized about regression insignificance, f-statistic $=2184$, which is significantly critical values at any reasonable level of significance, so in General the regression equation is significant.

Model $3(\mathrm{H} 2)$ : When the regression significance test was performed, F-statistic $=24$ was obtained, which is greater than the critical value, this suggests that Model 3 is generally significant.

During the Broich-Pagan test for models 1 and 3, statistics not exceeding critical values were obtained, which means that the model there is no problem of heteroskedasticity.

Next, a VIF test was performed to test multicollinearity for models 1 and 3 (Table 7). 
Table 7. VIF test of the first and third models

\begin{tabular}{|c|c|c|}
\hline \multirow[t]{2}{*}{ Variable } & \multicolumn{2}{|c|}{ VIF } \\
\hline & Model $1(\mathrm{H} 1)$ & Model $3(\mathrm{H} 2)$ \\
\hline TA & 1.033 & 1.15 \\
\hline Q & 1.019 & \\
\hline $\mathrm{ROA}$ & & 2.40 \\
\hline $\mathrm{DE}$ & 1.289 & 3.01 \\
\hline EPS & & 2.82 \\
\hline published & 1.110 & 1.15 \\
\hline
\end{tabular}

The VIF of all explanatory variables is about 1, thus, the absence of multicollinearity in models 1 and 3 is confirmed. Accordingly, $\mathrm{H} 1$ about the presence of a positive effect are confirmed.

Next, it was interesting to see if there was an impact on the horizon of more than one year. Model 2 (H1) and Model $4(\mathrm{H} 2)$ were constructed to analyze the longer-term effect (Table 8).

Table 8. Coefficients for model 2 (H1) and 4 (H2)

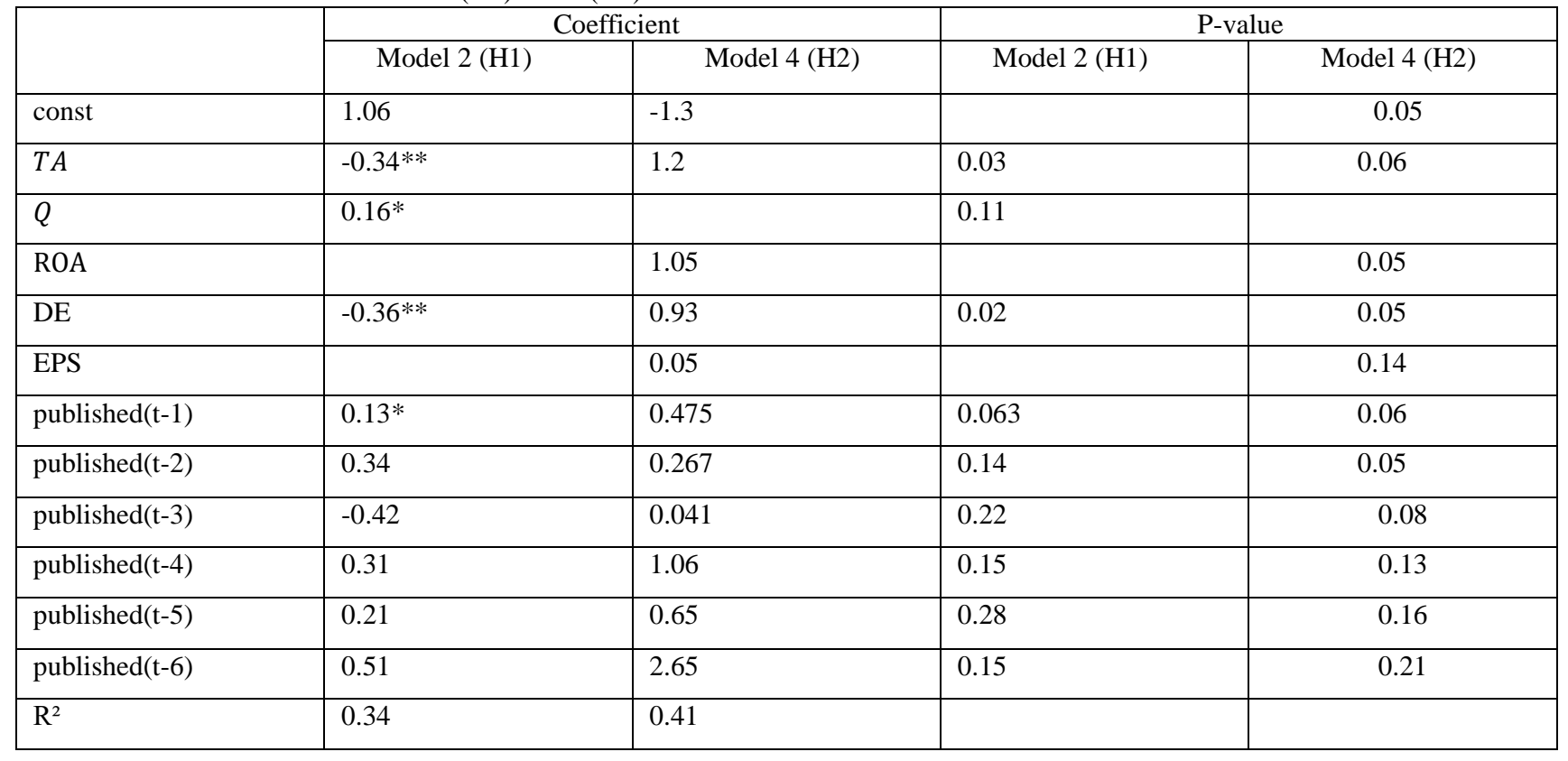

During the Broich-Pagan test for models 2 and 4, statistics not exceeding critical values were obtained, which means that the model there is no problem of heteroscedasticity (Table 9). 
Table 9. Second model VIF test:

\begin{tabular}{|c|c|c|}
\hline \multirow[t]{2}{*}{ Variable } & \multicolumn{2}{|c|}{ VIF } \\
\hline & Model $2(\mathrm{H} 1)$ & Model $4(\mathrm{H} 2)$ \\
\hline TA & 1.167 & 3.11 \\
\hline $\mathrm{Q}$ & 1.402 & \\
\hline $\mathrm{ROA}$ & & 2.16 \\
\hline $\mathrm{DE}$ & 1.004 & 1.09 \\
\hline EPS & & 1.97 \\
\hline published(t-1) & 2.793 & 2.13 \\
\hline published(t-2) & 2.536 & 2.35 \\
\hline published(t-3) & 1.364 & 3.14 \\
\hline published(t-4) & 1.866 & 1.96 \\
\hline published(t-5) & 2.004 & 2.14 \\
\hline published(t-6) & 1.646 & 3.11 \\
\hline
\end{tabular}

Thus, H2 confirmed, we can argue that the publication of non-financial statements also affects the financial performance in the longer term.

Next, we check the implementation of the third (H3) and fourth hypothesis (H4) that the presence of non-financial reporting publication has a positive effect on the Q-Tobina not in all industries. To do this, regressions were constructed for each individual industry, and by analogy with the testing of the first and second hypotheses, a regression was first constructed, in which the variable "published" of period t was included, and then" published " of the previous periods. It should be noted that in each sector there are from 8 to 20 companies, but to build a regression on two observations does not make sense, so it was decided to build regressions only for five sectors in which there are at least 10 companies: Basic Materials, Energy, Financial, Industrial, Utilities. It is worth noting that in the energy sector, each company at least once published non-financial statements, but there are many observations when in a particular year, less than half of the companies disclosed information, so at this stage we will consider including the energy industry.

So, first, five additional regressions were constructed for each of the five selected sectors.

Regression explained the Q-Tobin gain $\frac{Q_{t+1}-Q_{t}}{Q_{t}}$, investigated the significance of having a non-financial reporting reporting period $\mathrm{t}$ :

Model 5(H3)

$$
Q \text { deli }=\beta_{1}+\beta_{2} T A i+\beta_{3} Q i+\beta_{4} D E i+\beta_{5} \text { published }(t) i+U_{j}
$$

where $\mathrm{i}=1,2,3,4,5$ corresponds to the branch number.

Hypothesis three tested by analogy with the third, in the fourth hypothesis as the explained variable was the parameter increase ROA: $\frac{R O A_{t+1}-R O A_{t}}{R O A_{t}}$. As a model, the equation was constructed, which was used when 
testing hypothesis 2 on the impact of non-financial disclosure despite the increase in ROA, however, it was now considered separately for each industry:

Model 7(H4)

$$
\text { ROAdeli }=\beta_{1}+\beta_{2} T A i+\beta_{3} R O A i+\beta_{4} E P S i+\beta_{5} D E i+\beta_{6} \text { published }(t) i+U_{j}
$$

where $\mathrm{i}=1,2,3,4,5$ corresponds to the branch number.

The following coefficients were obtained (Table 10):

Table 10. Coefficients for model 5 (H3) and 7 (H4)

\begin{tabular}{|c|c|c|c|c|c|c|c|c|}
\hline & const & $T A$ & $\mathrm{Q}$ & ROA & EPS & $\mathrm{DE}$ & published & $\mathrm{R}^{2}$ \\
\hline $\begin{array}{l}\text { Basic materials, } \\
\text { Coef (H5) }\end{array}$ & $2.1 *$ & 0.06 & $1.2 * *$ & & & $-1.0 * * *$ & $0.11 * *$ & 0.34 \\
\hline $\begin{array}{l}\text { Basic materials, } \\
\text { Coef }(\mathrm{H} 7)\end{array}$ & 1.4 & $0.04^{*}$ & & $0.8^{* * *}$ & 1.6 & $-2.1^{* * *}$ & -0.04 & 0.38 \\
\hline $\begin{array}{l}\text { Basic materials, } \\
\text { p-value (H5) }\end{array}$ & 0.08 & 0.14 & 0.02 & & & 0.008 & 0.04 & \\
\hline $\begin{array}{l}\text { Basic materials, } \\
\text { p-value }(\mathrm{H} 7)\end{array}$ & 0.11 & 0.09 & & 0.004 & 0.14 & 0.006 & 0.13 & \\
\hline $\begin{array}{l}\text { Energy, } \\
\text { Coef (H5) }\end{array}$ & -1.8 & $0.003 * *$ & $0.15^{*}$ & & & -2.9 & 3.18 & 0.68 \\
\hline $\begin{array}{l}\text { Energy, } \\
\text { Coef (H7) }\end{array}$ & -3.4 & $1.04 * * *$ & & 2.4 & $-1.1 *$ & $0.46^{*}$ & $0.12 *$ & 0.48 \\
\hline $\begin{array}{l}\text { Energy, } \\
\text { p-value (H5) }\end{array}$ & 0.03 & 0.04 & 0.09 & & & 0.12 & 0.14 & \\
\hline $\begin{array}{l}\text { Energy, } \\
\text { p-value (H7) }\end{array}$ & 0.16 & 0.004 & & 0.19 & 0.09 & 0.07 & 0.1 & \\
\hline $\begin{array}{l}\text { Financial, } \\
\text { Coef (H5) }\end{array}$ & $0.1^{*}$ & $-1.2 *$ & $0.21 * *$ & & & $0.16^{*}$ & -0.9 & 0.22 \\
\hline $\begin{array}{l}\text { Financial, } \\
\text { Coef }(H 7)\end{array}$ & -1.6 & $0.20 * *$ & & $2.1 * *$ & $0.19 *$ & $-1.14 *$ & 0.3 & 0.52 \\
\hline $\begin{array}{l}\text { Financial, } \\
\text { p-value (H5) }\end{array}$ & 0.8 & 0.07 & 0.04 & & & 0.08 & 0.11 & \\
\hline $\begin{array}{l}\text { Financial, } \\
\text { p-value }(\mathrm{H} 7)\end{array}$ & 0.9 & 0.04 & & 0.04 & 0.1 & 0.09 & 0.14 & \\
\hline $\begin{array}{l}\text { Industrial, } \\
\text { Coef (H5) }\end{array}$ & 1.2 & $0.18 * * *$ & $1.2^{*}$ & & & $-0.4 *$ & -2.1 & 0.41 \\
\hline $\begin{array}{l}\text { Industrial, } \\
\text { Coef (H7) }\end{array}$ & 0.2 & $-0.8 *$ & & $1.4 *$ & 1.22 & -1.2 & $0.4^{*}$ & 0.26 \\
\hline $\begin{array}{l}\text { Industrial, } \\
\text { p-value (H5) }\end{array}$ & 0.16 & 0.009 & 0.07 & & & 0.09 & 0.18 & \\
\hline $\begin{array}{l}\text { Industrial, } \\
\text { p-value }(\mathrm{H} 7)\end{array}$ & 0.26 & 0.08 & & 0.06 & 0.18 & 0.19 & 0.09 & \\
\hline $\begin{array}{l}\text { Utilities, } \\
\text { Coef (H5) } \\
\end{array}$ & 1.4 & -0.8 & $1.0 * *$ & & & $-0.6 * *$ & $0.43^{*}$ & 0.36 \\
\hline $\begin{array}{l}\text { Utilities, } \\
\text { Coef (H7) } \\
\end{array}$ & $1.4 * *$ & 1.08 & & $-0.09 * *$ & 1.6 & $-1.3 * *$ & $0.71 *$ & 0.31 \\
\hline $\begin{array}{l}\text { Utilities, } \\
\text { p-value (H5) }\end{array}$ & 0.14 & 0.13 & 0.03 & & & 0.02 & 0.06 & \\
\hline $\begin{array}{l}\text { Utilities, } \\
\text { p-value }(\mathrm{H} 7)\end{array}$ & 0.04 & 0.11 & & 0.02 & 0.15 & 0.03 & 0.06 & \\
\hline
\end{tabular}


Significance tests indicated that all five equations are significant, also, according to the Broich-Pagan test, they lack heteroscedasticity.

(H3): as can be seen from the table, the availability of publication of non-financial statements the growth is positively affected by Q-Tobin not in all industries. Importance found only about the industries "basic materials" and "utilities".

(H4): as can be seen from the table, the availability of publication of non-financial statements not all industries have a positive impact on ROA growth. Importance found only about the industries "Energy", "Industrial" and "Utilities".

As a result of the analysis it was found that the publication of non-financial information has a positive effect on the growth of Q-Tobin's and ROA (hypothesis 1 and 2). Is worth it should be noted that the effect on Q-Tobin is manifested immediately in the year following reporting, and on ROA in the longer term: the effect is evident one year after the reporting year. This phenomenon is probably due to the fact that revaluation of market value by investors when information becomes available happens faster than the return on assets changes, so the effect on Q-Tobin is faster than on ROA.

However, you need to check how what impact takes place in more long term (Table 11-12).

Model 6(H3)

$$
\begin{aligned}
\text { Qdeli }=\beta_{1} & +\beta_{2} \text { TAi }+\beta_{3} Q i+\beta_{4} D E i+\beta_{5} \text { published }(t-1) i \\
& +\beta_{6} \text { published }(t-2) i+\beta_{7} \text { published }(t-3) i+\beta_{8} \text { published }(t-4) i \\
& +U_{j}
\end{aligned}
$$

where $\mathrm{i}=1,2,3,4,5$ corresponds to the branch number

Model 8 (H4)

$$
\begin{aligned}
\text { ROAdeli }= & \beta_{1}+\beta_{2} \text { TAi }+\beta_{3} \text { ROAi }+\beta_{4} \text { EPSi }+\beta_{5} \text { DE } i+\beta_{6} \text { published }(t-1) i \\
& +\beta_{7} \text { published }(t-2) i+\beta_{8} \text { published }(t-3) i+\beta_{9} \text { published }(t-4) i \\
& +U_{j}
\end{aligned}
$$

Table 11. Coefficients for model 6 (H3)

\begin{tabular}{|l|l|l|l|l|l|}
\hline $\begin{array}{l}\text { Variable } \\
\text { (chg_tobins_q) }\end{array}$ & Basic Materials & Energy & Financial & Industrial & Utilities \\
\hline TA & $-0,055$ & $-0,500^{* *}$ & $-0,551^{*}$ & $-0,21^{*}$ & $-0,511^{* *}$ \\
\hline $\mathrm{Q}$ & $-0,01^{*}$ & 0,01 & 0,019 & $-0,001$ & 0,008 \\
\hline DE & $-0,501^{* *}$ & $-0,344^{* *}$ & $-0,578^{*}$ & $-0,211^{*}$ & $-0,396^{* * *}$ \\
\hline published (-1) & $0,013^{*}$ & $0,016^{*}$ & 0,013 & $0,014^{*}$ & $0,01^{*}$ \\
\hline published (-2) & & & 0,014 & 0,006 & $0,007^{*}$ \\
\hline published (-3) & 0,010 & 0,013 & & & $0,018^{*}$ \\
\hline published (-4) & 0,006 & $0,017^{*}$ & 0,017 & $-0,007$ & 0,017 \\
\hline $\mathbf{R}^{\mathbf{2}}$ & $\mathbf{0 , 1 7 1}$ & $\mathbf{0 , 2 7 8}$ & $\mathbf{0 , 1 4 2}$ & $\mathbf{0 , 1 5 7}$ & $\mathbf{0 , 1 5}$ \\
\hline
\end{tabular}


Table 12. Coefficients for model 8 (H4)

\begin{tabular}{|l|l|l|l|l|l|}
\hline Variable (chg_roa) & Basic Materials & Energy & Financial & Industrial & Utilities \\
\hline intercept & $-0,02$ & 0,013 & $-0,009$ & $-0,002$ & 0,003 \\
\hline eps & $0,07^{*}$ & $0,081^{*}$ & 0,029 & 0,048 & $0,065^{*}$ \\
\hline tot_assets & $-0,365^{* *}$ & $-0,694^{* *}$ & $-0,568^{*}$ & $-0,408^{* *}$ & $-0,581^{* *}$ \\
\hline debt_to_assets & $-0,648^{* * *}$ & $-0,25^{* * *}$ & $-0,475^{* * *}$ & $-0,312^{* *}$ & $-0,445^{* * *}$ \\
\hline published (-1) & $0,012^{*}$ & $0,029^{* *}$ & 0,003 & 0,006 & 0,016 \\
\hline published (-2) & & & 0,003 & 0,004 & $0,014^{*}$ \\
\hline published (-3) & 0,016 & 0,008 & & & $0,018^{*}$ \\
\hline published (-4) & $0,018^{*}$ & $0,022^{*}$ & 0,015 & 0,016 & 0,018 \\
\hline published (-5) & & $0,012^{*}$ & & 0,012 & \\
\hline published (-6) & 0,015 & $0,015^{*}$ & & & 0,021 \\
\hline $\mathbf{R}^{\mathbf{2}}$ & $\mathbf{0 , 2 1 8}$ & $\mathbf{0 , 3 1 5}$ & $\mathbf{0 , 2 0 1}$ & $\mathbf{0 , 1 6 7}$ & $\mathbf{0 , 1 6 9}$ \\
\hline
\end{tabular}

The results of the study indicate that the effect of the publication of non-financial statements depends on the industry of the company. Hypotheses 3 and 4 that there is a positive effect from the publication of non-financial reporting on Q-Tobin (H3) and ROA (H4) not all industries have also been confirmed. Interestingly, the financial sector lacks any meaningful the impact of the publication of non-financial information on the financial performance.

\section{Conclusions}

First, we note that in General, the impact of the publication of non-financial this has a longer term effect on ROA gains and more the effect on the Q-Tobin coefficient increase that is, the effect on Q-Tobin manifests itself faster. This can be explained by the fact that $\mathrm{Q}$ is Tobin -short-term / medium-term revaluation of the company's value by investors based on a change in the existing dataset, while the ROA -directly reflects the success of the company in terms of more the fundamental indicator is net profit, which changes over a longer period of time.

Secondly, we note that the analysis by sector gives more accurate picture of how non-financial information has a big effect on the financial indicators. Thus, the impact of the publication of non-financial statements had a significant positive effect on the growth of Q-Tobin in next year only in sectors such as Basic Materials and Utilities, while while the effect on ROA growth in the following year was found in - Energy, Industrial, Utilities. It is worth noting that in all regressions the $\mathrm{R}^{2}$ is small, that is the explanatory power of the models is not very high, so the results cannot be to be considered unconditional. This is easily explained by the fact that much of the recent change in financial indicators was due to changes in market conditions and non-financial factors that are not taken into account in the model. Nevertheless, the results indicate the presence of intersectoral differences. Note that the long-term effect (the largest lag) non-financial information is observed in such industries as Energy, Basic Materials, Utilities; what can also find a reasonable explanation.

The model based on companies from the energy sector has sufficiently high explanatory force $\mathrm{R} 2=0,315$. Just like in others for example, the Broich-pagan test was conducted, which did not reject the hypothesis that the variance of individual effects is zero, as well as the VIF test, showed the absence of multicollinearity. 


\section{ENTREPRENEURSHIP AND SUSTAINABILITY ISSUES}

ISSN 2345-0282 (online) http://jssidoi.org/jesi/

2019 Volume 7 Number 2 (December)

http://doi.org/10.9770/jesi.2019.7.2(61)

Note also that for the financial sector the publication is non-financial information did not have a significant impact on financial indicators in any in the short term, nor in the long term. In general, the financial sector appears to be less focused on social issues, such as environmental concerns and social welfare.

\section{References:}

Crowther, D, Aras, G. 2009. Corporate Sustainability Reporting: A Study in Disingenuity? Journal of business ethics, Springer, 87, 279. https://doi.org/10.1007/s10551-008-9806-0

Daizy, D., Das, N. 2014. Sustainability Reporting Framework: Comparative Analysis of Global Reporting Initiatives and Dow Jones Sustainability Index. International Journal of Science. Environment and Technology, 3(1), 55-66. http://www.ijset.net/journal/493.pdf

Freedman, M., Stagliano, A. J. 1991. Differences in Social-Cost Disclosures: A Market Test of Investor Reactions. Accounting Auditing and Accountability Journal, 4(1): 68-83. https://doi.org/10.1108/09513579110142480

Garcia, A., López, V., Rodriguez, L. 2007. Sustainable Development and Corporate Performance: A Study Based on the Dow Jones Sustainability Index. Journal of Business Ethics, Springer, 75(3), 285-300. https://doi.org/10.1007/s10551-006-9253-8

Hohnen, P. 2012. The Future of Sustainability Reporting. EEDP Programme Paper. Chatham House, London. https://www.chathamhouse.org/sites/default/files/public/Research/Energy,\%20Environment\%20and\%20Development/0112pp_hohnen.pdf

Iatridis, G. 2013. Environmental disclosure quality: Evidence on environmental performance, corporate governance and value relevance. Emerging Markets Review, 15(3), 579-653. https://doi.org/10.1016/j.ememar.2012.11.003

Moore, G. M. 2001. Corporate Social Performance: An Investigation in the U.K. Supermarket Industry. Journal of Business Ethics, 14, 5575. https://doi.org/10.1023/A:101253701

Niskala, M., Schadewitz, H.J. 2010. Communication via responsibility reporting and its effect on firm value in Finland. Corporate Social Responsibility and Environmental Management, 17(2), 96-106. https://doi.org/10.1002/csr.234

Pava, M. L., Krausz, J. 1996. The Association between Corporate Social-Responsibility and Financial Performance: The Paradox of Social Cost. Journal of Business Ethics, 15(3), 579-653. https://doi.org/10.1007/978-94-007-4126-3 30

Preston, L.E, O'Bannon, D.P. 1997. The Corporate Social-Financial Performance Relationship: A Typology and Analysis. Business and Society, 36(4), 419-429. https://doi.org/10.1177/000765039703600406

Schreck, P. 2011. Reviewing the Business Case for Corporate Social Responsibility: New Evidence and Analysis. Journal of Business Ethics, Springer, 103(2), 167-188. https://doi.org/10.1007/s10551-011-0867-0

Siegel, D, McWilliams, A. 2000. Corporate Social Responsibility and Financial Performance: Correlation or Misspecification. Strategic Management Journal, 21(5), 603-609. https://doi.org/10.1002/(SICI)1097-0266(200005)21:5<603::AID-SMJ101>3.0.CO;2-3

Soana, 2011. The relationship between corporate social performance and corporate financial performance in the banking sector. Journal of Business Ethics, 104(1), 133-148. https://doi.org/10.1007/s10551-011-0894-x

Vafaei, A., Taylor, D., Ahmed, K. 2011. The value relevance of intellectual capital disclosures. Journal of Intellectual Capital, 12(3), 407429. https://doi.org/10.1108/14691931111154715

GRI. (2019). Sustainability Reporting https://www.globalreporting.org/information/sustainability-reporting/Pages/default.aspx 


\section{ENTREPRENEURSHIP AND SUSTAINABILITY ISSUES}

ISSN 2345-0282 (online) http://jssidoi.org/jesi/ 2019 Volume 7 Number 2 (December) http://doi.org/10.9770/jesi.2019.7.2(61)

Alex BORODIN is the Professor, Doctor of economic science at Plekhanov Russian University of Economics. Research interests: finance and regional development; innovation and digitalization; project management; sustainability

ORCHID ID: orcid.org/0000-0002-2872-1008

Nataliya SHASH is the Professor, Doctor of economic science at Plekhanov Russian University of Economics. Research interests: corporate and public finance management; investment designing; project management; sustainability

ORCHID ID: orcid.org/0000-0003-2779-6961

Galina PANAEDOVA is the Professor, Doctor of economic science at North-Caucasus federal university. Research interests: regional development; innovation and marketing; project management; tourism, world economy.

ORCHID ID: https://orcid.org/0000-0001-8261-6308

Svetlana FRUMINA, PhD, associate professor, Financial University under the Government of Russian Federation. Research interests: finance; innovation and marketing; education management; regional development.

ORCHID ID: orcid.org/0000-0001-5143-9417

Aidyn KAIRBEKULY PhD DBA, Nazarbaev Intellectual School in Semey city. Research interests: finance and regional development; regional development; innovation and marketing; project management; tourism.

ORCHID ID: orcid.org/0000-0001-922

Irina MITYUSHINA, Assistant of the Department of Innovative Economics and Finance, Belgorod National Research University. Research interests: Economics and Finance, corporate Finance, innovation Economics, digital Economics, financial computing

ORCID: orcid.org/0000-0003-3566-5654

Register for an ORCID ID:

https://orcid.org/register

Copyright (C) 2019 by author(s) and VsI Entrepreneurship and Sustainability Center

This work is licensed under the Creative Commons Attribution International License (CC BY).

http://creativecommons.org/licenses/by/4.0/

(c) (i) Open Access 